\title{
AKTIVITAS BERMAIN DOMINO SEBAGAI MEDIA UNTUK MENINGKATKAN KEMAMPUAN FUNGSI KOGNITIF BERHITUNG PADA LANSIA
}

\author{
Yusti Muzdalifa Taplo \\ Agnes Madianung \\ Esrom Kanine \\ Program Studi Ilmu Keperawatan Fakultas Kedokteran \\ Universitas Sam Ratulangi \\ Email : ymusdalifa@gmail.com
}

\begin{abstract}
Abstrack: Dominoes is one leisure activity that is familiar and easy to be played by all ages, including the elderly. When playing dominoes then the elderly will feel relaxed and relaxes the mind that stimulates brain cells that eventually can maintain cognitive function, one numeracy. The Aim of the research to know the activity of playing domino as a medium to improve cognitive function counting on the elderly. The method of this research uses quasi experiment, research design with pretest-posttest approach with control group. Samples with the technique of sampling non probability sampling is carried out, using the method of total sampling total sample with as many as 40 respondents. The results of research using the Mann Whitney test at 95\% significance level, obtained significant value that is 0.007 or smaller than the value of significance $0.05(0.007<0.05)$. Conclusion, the results show that the activity of playing dominoes can improve the cognitive functions of the elderly so that it can be used as counting as one of the relaxing activities to enhance cognitive function of elderly, especially counting ability.
\end{abstract}

Keywords: Activities Playing Domino, Math Ability

\begin{abstract}
Abstrak: Permainan domino adalah salah satu aktivitas santai yang familiar dan mudah dimainkan oleh berbagai usia termasuk kelompok lanjut usia. Ketika bermain domino maka lansia akan merasa santai dan merilekskan pikiran sehingga menstimulasi sel-sel otak yang akhirnya dapat mempertahankan fungsi kognitif, salah satunya kemampuan berhitung. Tujuan penelitian untuk mengetahui aktivitas bermain domino sebagai media untuk meningkatkan kemampuan fungsi kognitif berhitung pada lansia. Metode penelitian ini menggunakan desain penelitian quasi eksperimen, dengan pendekatan pretest-posttest with conrol grup. Sampel dengan teknik pengambilan sampel dilakukan secara non probability sampling, menggunakan metode total sampling dengan jumlah sampel sebanyak 40 responden. Hasil penelitian dengan menggunakan uji Mann Whitney pada tingkat kemaknaan 95\%, didapat bahwa nilai signifikan adalah 0,007 atau lebih kecil dari nilai signfikan $0,05(0,007<0,05)$. Kesimpulan, hasil penelitian ini menunjukan bahwa aktivitas bermain domino dapat meningkatkan kemampuan fungsi kognitif berhitung lansia sehingga bisa dijadikan sebagai salah satu aktivitas santai untuk meningkatkan fungsi kognitif lansia, khususnya kemampuan berhitung.
\end{abstract}

Kata kunci: Aktivitas Bermain Domino, Kemampuan Berhitung 


\section{PENDAHULUAN}

Lanjut usia menurut Presiden RI dalam Undang-Undang Republik Indonesia Nomor 13 tahun 1998 tentang Kesejahteraan Lansia, adalah seseorang yang telah mencapai usia 60 tahun ke atas. Lanjut usia merupakan tahap lanjut dari proses tumbuh kembang yang dimulai sejak lahir, berlangsung secara alamiah, dan terus-menerus (Triwibowo \& Puspita, 2014). Lansia menjadi salah satu masalah global yang tengah terjadi saat ini. Hal ini disebabkan oleh besarnya populasi lansia diseluruh dunia. Data statistik Amerika Serikat melaporkan bahwa jumlah lansia didunia berdasarkan kelompok umur pada Januari 2018 sebanyak 2,57 miliar dari 7,53 miliar orang. Peningkatan komposisi lansia dapat menjadi beban bagi negara maju ataupun berkembang seperti Indonesia karena mengalami masalah penurunan kesehatan. Sehingga dibuat program Substinable Development Goals untuk menjamin kesehatan seluruh masyarakat termasuk lansia (US Cencus Bureau, 2018)

Jumlah lansia di Indonesia dalam kurun waktu 4 tahun terus mengalami peningkatan. Menurut data dari Badan Pusat Statistik, pada tahun 2014 terdapat 18,8 juta, pada tahun 2015 terdapat 21,8 juta dan terus meningkat pada tahun 2016 menjadi 22,6 juta serta menjadi 23,6 juta pada tahun 2017. Berdasarkan data proyeksi, pada tahun 2018 jumlah lansia diperkirakan mencapai 9,3\% atau 24,7 juta jiwa. Diprediksi jumlah penduduk lansia tahun 2020 mencapai 27,08 juta, tahun 2025 mencapai 33,69 juta, tahun 2030 mencapai 40,95 juta dan tahun 2035 mencapai 48,19 juta (BPS, 2018).

Peningkatan terhadap jumlah lansia ini akibat dari meningkatnya usia harapan hidup lansia di Indonesia. Dari tahun ke tahun Indonesia terus mengalami peningkatan angka harapan hidup dalam kurun waktu 2010 hingga 2017. Badan Pusat Statistik melalui Depkes 2018, melaporkan adanya peningkatan usia harapan hidup lansia pada tahun 2010 adalah 69,8 tahun (dengan presentase populasi lansia sebesar 7,56\%) dan secara bertahap meningkat hingga mencapai 71,06 tahun pada tahun 2017 (dengan presentase populasi lansia sebesar 9,03\%). Dan diperkirakan akan meningkat menjadi 72,5 tahun pada 2035 (dengan presentase populasi lansia sebesar $15,8 \%$ ). Peningkatan usia harapan hidup lansia terjadi akibat adanya perbaikan status kesehatan masyarakat termasuk peningkatan akses kualitas pelayanan kesehatan.

Meningkatnya usia harapan hidup pada lansia maka dapat menimbulkan beberapa penyakit pada lansia. Berdasarkan data dari artikel yang ditulis oleh Lisabetta di California (2017) melaporkan bahwa salah satu penyakit yang banyak terjadi pada lansia adalah penyakit degeneratif. Penyakit degeneratif pada lansia terdiri dari beberapa jenis, salah satunya adalah kerusakan saraf otak atau penurunan kognitif (pikun). Berdasarkan penelitian Ogawa, et al (2018) yang dilakukan pada 483 lansia dari usia 6089 tahun menunjukkan bahwa semakin meningkatnya umur lansia maka fungsi kognitifnya akan semakin menurun.

Fungsi kognitif akan mengalami penurunan secara normal seiring dengan penambahan usia. Selain itu, ada faktor risiko yang dapat memengaruhi penurunan fungsi kognitif. Menurut artikel yang ditulis oleh Stibich (2017) menunjukkan bahwa beberapa faktor resiko yang dapat mempengaruhi fungsi kognitif antara lain faktor genetik, faktor fisiologis (usia, tingkat glukosa darah, obesitas, stroke, danpenyakit kronis), dan faktor gaya hidup (aktivitas fisik, depresi, obat-obatan, \& alkohol).

Akibat dari penurunan fungsi kognitif maka akan berdampak pada kehidupan lansia sehari-hari. Menurut penelitian yang dilakukan Santos, et al (2018) yang dilakukan kepada penderita demensia dan penderita demensia dengan penyakit diabetes, didapatkan hasil bahwa dampak gangguan kognitif demensia bagi kehidupan mereka adalah kurangnya kepercayaan diri, malu, dan khawatir dengan perubahan peran dimana penderita tidak bisa mandiri dan masih butuh bantuan orang lain untuk melakukan aktivitas sehari-hari. Untuk itu, perlu dilakukan upaya untuk mempertahankan fungsi kognitif pada lansia. 
Upaya yang dapat dilakukan untuk mempertahankan fungsi kognitif yaitu dengan cara meningkatkan aktivitas yang bisa menstimulasi otak. Berdasarkan penelitian yang dilakukan oleh Turana (2014) tentang hubungan antara kemampuan kognitif dan aktivitas santai (bermain catur, musik, atau kartu). Diperoleh data bahwa mereka yang melakukan banyak aktivitas diwaktu luang, sampai usia 36 tahun, memiliki memori yang lebih baik saat usia mencapai 43 tahun. Penelitian lain juga menunjukkan hal yang hampir sama bahwa dengan banyak melakukan aktivitas yang bisa menstimulasi otak, seperti membaca, menulis, bermain puzzle, bermain catur, bermain kartu, diskusi dalam grup, dan bermain musik, pada lansia bisa menghambat proses hilangnya memori.

Aktivitas santai yang dapat dilakukan yaitu bermain menggunakan media kartu domino. Kartu domino merupakan permainan yang digemari dan sudah melekat pada diri masyarakat Indonesia. Permainan domino adalah permainan familiar dan mudah dimainkan oleh berbagai usia termasuk kelompok lanjut usia. Ketika bermain domino maka lansia akan merasa santai dan merilekskan pikiran sehingga menstimulasi sel-sel otak yang akhirnya dapat mempertahankan fungsi kognitif, salah satunya kemampuan berhitung.

Berdasarkan studi pendahuluan yang telah dilakukan oleh peneliti di Panti Werdha didapatkan keterangan melalui wawancara dengan 4 lansia bahwa yaitu tanggal 8 September 2018, terdapat beberapa lansia tidak mengetahui tanggal lahir dan usianya, tidak menjawab soal perhitungan dengan benar serta lansia jarang melakukan aktivitas, sehari-hari lansia hanya mengikuti ibadah selain itu, lansia tidak melakukan aktivitas apapun. Serta belum pernah dilakukan aktivitas bermain domino untuk meningkatkan kemampuan kognitif lansia. Berdasarkan uraian diatas, peneliti tertarik untuk meneliti apakah aktivitas bermain domino sebagai media dapat meningkatkan kemampuan berhitung pada lansia

\section{METODE PENELITIAN}

Jenis penelitian yang digunakan adalah quasi eksperimen dengan pendekatan pretest-posttest with control group. Penelitian dilaksanakan di Panti Werdha Damai Ranomuut dan BPLU Senja Cerah Mapanget pada tanggal 05-24 November 2018. Populasi penelitian ini adalah seluruh lansia di Panti Werdha Damai Ranomuut yang berjumlah 23 dan BPLU Senja Cerah Mapanget yang berjumlah 55. Sampel yang digunakan pada penelitian ini adalah 20 lansia di Panti Werdha Damai Ranomuut dan 20 lansia BPLU Senja Cerah Mapanget. Instrumen yang digunakan untuk mengukur kemampuan berhitung kuisioner MMSE dan lembar observasi.

Variabel bebas dalam penelitian ini adalah aktivitas bermain domino sedangkan variabel terikat adalah kemampuan berhitung lansia. Analisa bivariat adalah analisa yang dilakukan terhadap dua variabel dari penelitian yang dianggap saling mempengaruhi. Analisa bivariat dalam penelitian ini yaitu untuk mengetahui aktivitas bermain domino untuk meningkatkan kemampuan berhitung lansia di Panti Wherda Damai Ranomuut dan BPLU Senja Cerah Mapanget. Sebelum menentukan uji yang akan dipakai dalam penelitian ini, peneliti menguji data apakah berdistribusi normal atau tidak. Peneliti menguji data dengan uji Shapiro wilk, hasil uji normalitas didapatkan bahwa data berdistribusi tidak normal. Hal ini dapat dilihat dari nilai $\mathrm{p}$-value yang nilainya lebih kecil dari nilai probabilitas $(\mathrm{p}<0,05)$. Hal ini juga berdampak dengan variabel penelitian sehingga lebih lanjut penelitian ini menggunakan uji non parametric test yaitu uji Wilcoxon untuk menguji 2 sampel yang berpasangan pada masing-masing kelompok dan uji Mann Whitney untuk menguji perbedaan pada 2 sampel yang tidak berpasangan pada tingkat kemaknaan $95 \%$ $(\alpha=0,05)$. 
HASIL DAN PEMBAHASAN

1. Karakteristik Lansia pada Kelompok Intervensi

Tabel 1. Distribusi Frekuensi Data Demografi Responden pada Kelompok Intervensi

\begin{tabular}{ccc}
\hline Variabel & $\mathrm{n}$ & $\%$ \\
\hline Jenis Kelamin & & \\
Perempuan & 20 & 100 \\
Total & 20 & 100 \\
\hline Umur & & \\
60-74 tahun & 11 & 55 \\
$75-90$ tahun & 9 & 45 \\
Total & 20 & 100 \\
\hline Fungsi & & \\
Kognitif & 7 & 35 \\
Normal & 10 & 50 \\
Ringan & 3 & 15 \\
Berat & 20 & 100 \\
Total & & \\
\hline
\end{tabular}

Sumber: Data Primer 2018

Hasil analisa pada tabel 1 dapat disimpulkan bahwa dari 20 responden kelompok intervensi distribusinya mayoritas jenis kelamin responden yaitu perempuan terdapat 20 responden $(100 \%)$, mayoritas usiayaitu ada di rentang umur 60-74 tahun sebanyak $11(55 \%)$ responden sehingga digolongkan pada kategori usia tuadan mayoritas fungsi kognitif yaitu ringan terdapat $10(50 \%)$ responden.
2. Karakteristik Lansia pada Kelompok Kontrol

Tabel 2. Distribusi Frekuensi Data Demografi Responden pada Kelompok Kontrol

\begin{tabular}{ccc}
\hline Variabel & $\mathrm{n}$ & $\%$ \\
\hline Jenis Kelamin & & \\
Perempuan & 20 & 100 \\
Total & 20 & 100 \\
\hline Umur & & \\
60-74 tahun & 8 & 40 \\
75-90 tahun & 12 & 60 \\
Total & 20 & 100 \\
\hline Fungsi & & \\
Kognitif & 8 & 40 \\
Normal & 7 & 35 \\
Ringan & 5 & 25 \\
Berat & 20 & 100 \\
Total & & \\
\hline
\end{tabular}

Sumber: Data Primer 2018

Hasil analisa pada tabel 2 dapat disimpulkan bahwa dari 20 responden kelompok kontrol distribusinya mayoritas jenis kelamin responden yaitu perempuan terdapat 20 responden (100\%), usia mayoritas yaitu ada di rentang umur 75-90 tahun sebanyak $12(60 \%)$ responden sehingga digolongkan pada kategori usia sangat tua dan mayoritas data fungsi kognitif yaitu normal terdapat 8 responden $(40 \%)$.

Wanita lebih berisiko mengalami penurunan kognitif. Hal ini disebabkan adanya peranan level hormon seks endogen dalam perubahan fungsi kognitif. Reseptor estrogen telah ditemukan dalam area otak yang berperan dalam fungsi belajar dan memori, seperti hipokampus. Rendahnya level estradiol dalam tubuh telah dikaitkan dengan penurunan fungsi kognitif umum dan memori verbal. Ekstradiol diperkirakan bersifat neuroprotektif dan dapat membatasi kerusakan akibat stres oksidatif serta terlihat sebagai protektor sel saraf dari toksisitas amiloid pada pasien Alzheimer (Roberts \& Petersen, 2015). Sedangkan mayoritas umur berada pada rentang 75-90 tahun sebanyak 12 orang $(60 \%)$. Sesuai dengan penelitan 
yang dilakukan Sundariyati et al., (2014) terhadap 84 responden berusia 60-90 tahun untuk mengukur penurunan kognitif pada lanjut usia menunjukkan bahwa responden berusia 60-74 sebesar 6,9\%, 75-90 sebesar $9,6 \%$ dan > 90 sebesar $100 \%$. Hasil penelitian tersebut menunjukkan adanya hubungan positif antara usia dan penurunan fungsi kognitif serta mayoritas fungsi kognitif pada responden yaitu gangguan fungsi kognitif ringan sebanyak 10 orang $(50 \%)$.

3. Kemampuan Berhitung Responden Pretest dan Posttest pada Kelompok Intervensi dan Kelompok Kontrol

Tabel 3. Distribusi Kemampuan Berhitung Responden Pretest dan Posttest pada Kelompok Intervensi dan Kelompok Kontrol

\begin{tabular}{lcc}
\hline $\begin{array}{c}\text { Kemampuan } \\
\text { Berhitung }\end{array}$ & $\begin{array}{c}\text { Mean (Min- } \\
\text { Max) }\end{array}$ & $\begin{array}{c}\text { Median/S } \\
D\end{array}$ \\
\hline Intervensi & & \\
Pretest & $2,95(1-5)$ & $3,00 / 0,998$ \\
Posttest & $4,05(2-5)$ & $4,00 / 0,944$ \\
& & \\
\hline Kontrol & & \\
Pretest & $2,75(1-5)$ & $3,00 / 1,251$ \\
Posttest & $2,95(1-5)$ & $3,00 / 1,276$
\end{tabular}

Sumber: Data Primer 2018

Berdasarkan hasil uji statistik pada tabel 3 menunjukkan bahwa rata-rata kemampuan berhitung pada hari pertama kelompok intervensi yaitu 2,95 dengan standar deviasi 0,998 , sedangkan pada hari pertama kelompok kontrol rata-ratanya lebih rendah dari kelompok intervensi yaitu 2,75 dengan standar deviasi 1,251. Dan rata-rata kemampuan berhitung pada hari terakhir kelompok intervensi yaitu 4,05 dengan standar deviasi 0,944, sedangkan pada hari terakhir kelompok kontrol rata-ratanya lebih rendah daripada kelompok kontrol yaitu 2,95 dengan standar deviasi 1,276.
4. Kemampuan Berhitung Pretest-Posttest Responden Kelompok Kontrol

Tabel 4. Analisis Pretest-Posttest Kemampuan Berhitung Responden Kelompok Kontrol

\begin{tabular}{lccc}
\hline \multicolumn{1}{c}{ Variabel } & Mean & $S D$ & $p$-value \\
\hline $\begin{array}{l}\text { (Pretest) } \\
\text { Hari ke-1 }\end{array}$ & 2,75 & 1,251 & 0,046 \\
$\begin{array}{l}\text { (Posttest) } \\
\text { Hari ke-3 }\end{array}$ & 2,95 & 1,276 & \\
\hline
\end{tabular}

Sumber: Data Primer 2018

Hasil uji Wilcoxon pada tabel 4 responden mengalami perbedaan rerata dilihat dari nilai meannya pada hari yang diukur yaitu hari pertama sebesar 2,75 dan meningkat menjadi 2,95 pada hari ketiga serta nilai $p$-value $0,046(<0,05)$. Dengan demikian dapat disimpulkan bahwa terdapat perbedaan rerata kemampuan berhitung pretest-posttest pada kelompok kontrol. Dan menunjukkan adanya pengaruh aktivitas bermain domino terhadap kemampuan berhitung pada kelompok kontrol. Perbedaan rerata pada kelompok kontrol hasil rerata kemampuan berhitung sebelum dan sesudahnya belum mencapai keadaan normal atau hasilnya masih dibawah normal yaitu < 5 jawaban benar dalam kemampuan berhitung.

5. Kemampuan Berhitung Pretest-Posttest Responden Kelompok Intervensi

Tabel 5. Hasil Analisis Pretest-Posttest Kemampuan Berhitung Responden Kelompok Intervensi

\begin{tabular}{lccc}
\hline \multicolumn{1}{c}{ Variabel } & Mean & $S D$ & $p$-value \\
\hline $\begin{array}{l}\text { (Pretest) } \\
\text { Hari ke-1 }\end{array}$ & 2,95 & 0,998 & 0,000 \\
$\begin{array}{l}\text { Posttest) } \\
\text { Hari ke-10 }\end{array}$ & 4,05 & 0,944 & \\
\hline
\end{tabular}

Sumber: Data Primer 2018

Hasil uji Wilcoxon pada tabel 5 responden mengalami perubahan kemampuan berhitung dilihat dari nilai meannya yaitu hari pertama sebesar 2,95 dan meningkat menjadi 4,05 pada hari kesepuluh 
serta nilai p-value sama dengan $0,000(<0,05)$. Dengan demikian dapat disimpulkan bahwa terdapat perbedaan rerata kemampuan berhitung pretest-posttest pada kelompok intervensi. Dan menunjukkan adanya pengaruh yang signifikan aktivitas bermain domino terhadap kemampuan berhitung pada kelompok intervensi. Pada hasil pretestposttest kelompok intervensi yang diberikan aktivitas bermain domino sebanyak 10 kali menunjukkan bahwa terdapat perbedaan rerata yang signifikan kemampuan berhitung sebelum dan sesudah intervensi pada kelompok intervensi yaitu dengan nilai $\mathrm{p}$ value 0,000 .

6. Kemampuan Berhitung Posttest pada Kelompok Intervensi dan Kelompok Kontrol

Tabel 6. Analisis Perbedaan Rerata Kemampuan Berhitung Posttest pada Kelompok Intervensi dan Kelompok Kontrol

\begin{tabular}{lccc}
\hline Variabel & $n$ & $\begin{array}{c}\text { Mean } \\
\text { Rank }\end{array}$ & $\begin{array}{c}p- \\
\text { value }\end{array}$ \\
\hline $\begin{array}{l}\text { (Posttest) } \\
\text { Intervensi }\end{array}$ & 20 & 25,28 & 0,007 \\
$\begin{array}{l}\text { Hari ke-10 } \\
\text { (Posttest) }\end{array}$ & & & \\
$\begin{array}{l}\text { Kontrol } \\
\text { Hari ke-3 }\end{array}$ & 20 & 17,73 & \\
\hline
\end{tabular}

Sumber: Data Primer 2018

Hasil analisis tabel 6 diatas menunjukkan nilai rata-rata kemampuan berhitung pada posttest hari ke-10 kelompok intervensi yang diberikan aktivitas bermain domino adalah 25,28. Sedangkan nilai ratarata kemampuan berhitung pada posttest hari ke-3 kelompok kontrol yang diberikan aktivitas bermain domino adalah 17,73. Hasil uji statistik mendapatkan nilai $p$-value sama dengan 0,007 . Nilai $p$-value $\leq 0,05$, berarti terdapat perbedaan rerata kemampuan berhitung antara kelompok intervensi yang diberikan aktivitas bermain domino sebanyak 10 kali dan kelompok kontrol yang diberikan aktivitas bermain domino sebanyak 3 kali.
Aktivitas otak yang yang menyenangkan dapat memberikan stimulus pada otak dengan mengembangkan jalur saraf baru di otak sehingga dapat meningkatkan kemampuan kognitif dan meningkatkan memori otak. Hal tersebut terjadi ketika input sensorik diproses oleh korteks-korteks asosiasi, neuron kortikal mengirimkan impuls menuju lobus temporal medial yang meliputi hipokampus dan daerah korteks temporal sekitarnya. Daerah lobus temporal ini memainkan peran utama dalam konsolidasi memori dan akses memori dengan berkomunikasi dengan thalamus dan korteks prefrontal. Korteks prefrontal dan lobus temporal medial menerima input atau masukan dari Acetylcholine-releasing neuron yang terletak di basal otak depan. Percikan asetilkolin inilah yang diduga memungkinkan pembentukan suatu memori. Hilangnya masukan asetilkolin yang dilepas oleh neuron basal otak inilah yang dapat mengganggu proses pembentukan memori baru dan pengambilan memori lama. Memori akan dapat diingat kembali apabila seperangkat neuron yang sama seperti yang terlibat dalam pembentukan memori tersebut terstimulasi (Lumbantobing, 2005).

Penelitian yang berkaitan yaitu Dewi (2016) yang menyatakan bahwa dengan bermain puzzle 12 kali dalam sebulan kepada 48 lansia menunjukkan peningkatan fungsi kognitif dari gangguan fungsi kognitif moderat menjadi gangguan fungsi kognitif ringan yaitu sebanyak 12 responden. Sedangkan penelitian lain menyebutkan art theraphy yang dilakukan kepada lansia sebanyak 8 kali dalam sebulan menunjukkan adanya peningkatan fungsi kognitif sebelum dan sesudah diberikan art therapy yang memiliki kenaikan sebesar $10,5 \%$ yang berarti art therapy memberikan pengaruh untuk meningkatkan fungsi kognitif lansia (Putri, Nurrachmah, \& Gayatri, 2014). Penelitian yang dilakukan oleh Pradipta (2016) kepada 14 lansia bahwa terdapat perbedaan sebelum dan sesudah diberikan aktivitas bermain kartu ceki terhadap fungsi kognitif lansia pada kelompok kontrol dan intervensi. Dengan perbedaan hasil posttest 
intervensi dan kontrol pada fungsi kognitif sebesar 0,006 yang berarti kartu ceki berpengaruh terhadap peningkatan fungsi kognitif.

Berdasarkan penelitian ini peneliti berasumsi bahwa kemampuan berhitung pada kelompok kontrol yang diberikan aktivitas bermain domino sebanyak 3 kali hasil pretest-posttest rerata kemampuan berhitungnya masih dibawah normal disebabkan karena frekuensi bermain yang masih rendah. Sedangkan pada responden kelompok intervensi yang diberikan aktivitas bermain domino sebanyak 10 kali hasil rerata pretest responden yang masih dibawah normal dan setelah diberikan aktivitas bermain domino hasil rerata posttest responden sudah berada pada keadaan normal, ini berarti aktivitas bermain domino dapat meningkatkan kemampuan berhitung sehingga fungsi kognitif lansia dapat dipertahankan atau mencegah terjadinya penurunan pada responden dalam penelitian ini.

\section{SIMPULAN}

Berdasarkan hasil penelitian, maka kesimpulan yang bisa diambil, ialah:

1. Karakteristik responden pada penelitian ini adalah jenis kelamin mayoritas yaitu perempuan, usia mayoritas yaitu 75-90 tahun dan gangguan fungsi kognitif mayoritas yaitu gangguan fungsi kognitif ringan.

2. Kemampuan fungsi kognitif berhitung lansia pretest dan posttest pada kelompok intervensi di Panti Werdha Damai Ranomuut mengalami peningkatan sehingga dapat menghambat penurunan fungsi kognitif berhitung.

3. Kemampuan fungsi kognitif berhitung lansia pretest dan posttest pada kelompok kontrol di BPLU Senja Cerah Mapanget juga mengalami peningkatan dalam fungsi kognitif berhitung.

4. Terdapat perbedaan rerata kemampuan fungsi kognitif berhitung posttest antara kelompok intervensi di Panti Werdha Damai Ranomuut dan kelompok kontrol di Panti Jompo Senja Cerah Mapanget
5. Aktivitas bermain domino dapat meningkatkan kemampuan fungsi kognitif berhitung pada lansia di Panti Werdha Damai Ranomuut dan BPLU Senja Cerah Mapanget.

\section{DAFTAR PUSTAKA}

Badan Pusat Statistik. (2018). Statistik Indonesia2018. Jakarta : Badan Pusat Statistik.https://www.bps.go.id/publicat ion/2018/07/03/5a963c1ea9b0fed6497 d0845/statistik-indonesia2018.html Diakses pada tanggal 06 September 2018

Dewi, Sofia. (2016).Pengaruh Senam Otak dan Bermain Puzzle Terhadap Fungsi KognitifLansia di PLTU Jember Vol 1, Edisi

1.http://jurnal.poltekeskupang.ac.id/ind ex.php/jkp/article/download/69/68/.Dia kses pada tanggal 1 Desember 2018

Kementerian Kesehatan RI. (2018). Profil Kesehatan Indonesia 2017

Lisabetta Divita. (2017). List Degenerative Disease.https://www.livestrong.com/art icle/79131-list-degenerative-diseases/ diakses 21 September 2018

Lumbantobing, S. (2005). Kecerdasan pada Usia Lanjut dan Demensia. Jakarta: Balai Penerbit FKUI.

Ogawa, Masayo, et al. (2018). Analysis Of Risk Factors For Mild Cognitive Impairment Based On Word List Memory Test Results And Questionnaire Responses In Healthy Japanese Individuals Registered In An Online Database.doi.org/10.1371. https://journals.plos.org/plosone/article ?id=10.1371/journal.pone.0197466. Diakses pada tanggal 19 September 2018

Pradipta, Rifky. (2016). Efek Permainan Kartu Ceki Terhadap Tingkat Kognitif 
Dan Penurunan Gejala Frontotemporal Demensia Pada Lansia Di Kabupaten Madiun. Skripsi.Surabaya: Unair.

Presiden Republik Indonesia. (1998). Undang-Undang Republik Indonesia Nomor 13 Tahun 1998 Tentang Kesejahteraan Lansia. www.bphn.go.id/data/documents/98uu 013.pdf Diakses pada tanggal 06 September 2018

Putri, D. M., Nurrachman, E., \& Gayatri, Dewi. (2014). Pengaruh Latihan Senam Otak dan Art Therapy Terhadap Fungsi Kognitif Lansia dengan Demensia di PSTW Yogyakarta Unit Budi Luhur dan Abiyoso. https://osf.io/preprints/inarxiv /db3a9/download. Diakses pada tanggal 1 Desember 2018

Roberts \& Petersen. (2015). Risk And Protective Factors For Cognitive Impairment In Persons Aged 85 Years And

Older. doi: 10.1212/WNL.0000000000001537 .https://www.ncbi.nlm.nih.gov/pmc/arti cles/PMC4433468/. Diakses pada 12 Januari 2019

Santos, et al. (2018). The Impact Of Cognitive Impairment In Dementia On Self-Care Domains In Diabetes: A Systematic Search And Narrative Review. doi: 10.1002/dmrr.3013. https://www.ncbi.nlm.nih.gov/pubmed/ 29707902. Diakses pada 12 Januari $\underline{2019}$

Stibich, Mark. (2017). Cognitive Impairment Risk Factors for Men and Women.https://www.verywellmind.co $\mathrm{m}$ /preventing-cognitive-impairment2224108. Diakses pada 12 Januari 2019

Sundariyati, et al. (2014). Gambaran Faktor-Faktor Yang Mempengaruhi Status Kognitif Pada Lansia di Wilayah Kerja Puskesmas Kubu II. Skripsi.Bali: Universitas Udayana
Triwibowo, H \& Puspitasari, K. (2014). Hubungan Aktivitas Fisik Dengan Fungsi Kognitif Pada Lansia Di Desa Tanjungan Kec. Kemlagi Kab. Mojokerto Vol. 3, No. 2.https://www.ejournal.stikeswilliambo oth.ac.id/index.php/Kep/article/view/51 Diakses pada tanggal 03 September 2018

Turana, Yuda. (2014). Stop Pikun di Usia Muda. Jakarta: Gramedia Pustaka Utama

US Cencus Bureau. (2018). Berapa Jumlah Penduduk

Dunia.https://databoks.katadata.co.id/d atapublish/2018/04/23/berapa-jumlahpenduduk-dunia. Diakses 23 Oktober 2018 